AGEENKO V.A. (National University of Science and Technology “MISIS”, Moscow, Russia) TAVOSTIN M.N. (National University of Science and Technology "MISIS", Moscow, Russia) VAKULENKO I.S. (National University of Science and Technology "MISIS”, Moscow, Russia)

\title{
TRIAXIAL COMPRESSION TESTING OF FROZEN SOILS FOR THE DETERMINA- TION OF RHEOLOGICAL PARAMETERS
}

Detailed investigation of mechanical, deformation and rheological properties of frozen soils is an actual issue, as they are basis of civil-engineering survey for underground constructions in permafrost holding more than $50 \%$ of the territory of Russia. The majority of modern software packages which calculate structures stability considering stress state of soils massive, demand knowledge of mechanical and rheological parameters defined by triaxial compression tests.

The current article presents: estimation method of frozen soils rheological parameters by triaxial compression testing; required equipment and the research results. The samples of frozen soil $10-50 \mathrm{~m}$ depth from Kharasavey gas field were used as test material. Mostly they are presented by loam, clay and sand. The experiments were run at the range of temperature from $-3{ }^{\circ} \mathrm{C}$ to $-6{ }^{\circ} \mathrm{C}$.

Triaxial compression testing was provided by the laboratory equipment which allows to run experiments in the mode of automatic load, maintenance and deformation processes registration. Test procedure of rheological parameters identification under conditions of long-term triaxial compression considered incremental load Stage duration was equal to 24 hours. The experiments were run until th specimen's failure. As a result of the testing, mechanical, deformation and rheological parameters for frozen soils are defined at temperatures $-3{ }^{\circ} \mathrm{C}--6{ }^{\circ} \mathrm{C}$. The achieved results can be interpreted in different models (Mohr-Coulomb, Drucker-Prager, Tresca etc.).

The described experiments were carried out at LLC Gazprom Geotechnology for the design of underground drill cutting s storages in permafrost.

Keywords: testing of frozen soils, triaxial compression, rheological characteristics, geomechanics.

\section{Introduction}

Most of Russian territory is affected by seasonal soils freezing, while more than $50 \%$ of land inside the country is permafrost. Therefore, the design and construction of underground facilities on these territories are followed by essential issues. The mechanical properties of frozen soils constitute the basis for solving underground constructions geotechnical objectives. Due to underground constructions depth increase, it becomes necessary to define frozen soils mechanical properties by triaxial compression testing, which represents soils massive condition more objectively. This type of constructions is used for oil-gas industry (underground drill cuttings storages, wells for different purposes etc). Frozen soils parameters are relative also for the design of underground construction in water saturated soils by the method of artificial ground freezing.
Frozen soils properties containing their rheological effects are quite well investigated. There are technical regulations which describe how to define half-rock, dispersed and frozen soils strength and strain parameters by laboratory investigation (GOST 12248-2010). The main aim of it characteristics is to implement calculations of surface and near-surface facilities construction in conditions of uniaxial compression.

Meanwhile, often it is complicated to determine initial physical-mechanical properties of frozen soils by modern software applicable for underground constructions stability analysis (ABAQUS, ANSYS, PLAXIS), which estimate stress-strained state of soil massive.

\section{Objectives}

The aim of the article consists in the creation of laboratory analysis method which allows to determine rheological characteristics of frozen soils under conditions of triaxial 
compression. Such issues as laboratory equipment selection and tests conduction are considered in the article as well.

\section{Methods}

The method of rheological characteristics determination implies testing under condition of long-term creep. The basis of this method is incremental loading by triaxial compression apparatus. The method was implemented to define rheological parameters, which made possibility to lateral expanding of the sample under axisymmetric static loading conditions when $\sigma_{1} \geq \sigma_{2}=\sigma_{3}$. Where $\sigma_{1}-$ alternate axial stress; $\sigma_{2}=\sigma_{3}-$ constant lateral stresses.

Initially, sample is loaded by uniform pressure making stresses $\sigma_{1}=\sigma_{2}=\sigma_{3}$. The value of these stresses is planned experiment dimension, as the value of constant minimal stress $\sigma_{2}=\sigma_{3}$ which was measured by Eq. 1:

$$
\sigma_{2}=\sigma_{3}=\gamma \times H \text {, }
$$

where $\gamma-$ specific gravity of soil, $\mathrm{N} / \mathrm{m}^{3}$; $H$ - the depth of tested soil massive, $\mathrm{m}$.

The exposure of stresses $\sigma_{1}=\sigma_{2}=\sigma_{3}$ is maintained until the total loss of deformations. Later, axial stress $\sigma_{1}$ is increased by $\Delta \sigma_{1}$, while $\sigma_{2}$ and $\sigma_{3}$ are remained constant through the whole experiment. Each step duration equals to 24 hours. The value of loading at steps is measured by Eq. 2:

$$
\Delta \sigma_{1}=\frac{\sigma_{c} \times n}{10}
$$

where $\sigma_{c}-$ conditionally instantaneous value of ultimate uniaxial compression strength of soil, $\mathrm{kPa} ; n$-step number.

The testing is carried out until the sample failure $\mathrm{k}$ or it transition to increasing creep stage. Otherwise, if conditions mentioned above are not observed, the testing is run until axial strain reaches $20 \%$.

Laboratory equipment which is used for triaxial compression testing under conditions of long-term loading, should provide next conditions:

- axial load setting, sufficient to crash a sample (not lower than $15 \mathrm{kN}$ );

- lateral pressure setting $\sigma_{2}=\sigma_{3}$ (not lower than $0,4 \mathrm{MPa}$ ) and it maintenance during the whole experiment;
- continuous automatic recording of axial stress $\sigma_{1}$ and lateral pressure $\sigma_{2}=\sigma_{3}$;

- testing at negative temperature (up to $-10{ }^{\circ} \mathrm{C}$ )

- possibility of longitudinal and volumetric soil strain measuring;

Transverse strain $\varepsilon_{3}$ was calculated by Eq. 3:

$$
\varepsilon_{3}=\frac{\left(\varepsilon_{v}-\varepsilon_{1}\right)}{2},
$$

where $\varepsilon_{v}$ - relative volumetric strain of sample; $\varepsilon_{1}$ - relative vertical soil sample strain.

Tests were performed by laboratory complex "ASIS" designed by LLC NPP "Geotech". IT includes apparatus consisted of loading frame 1, triaxial compression chamber 2 (Fig. 1). The complex has lateral pressure stabilization mechanism 3 , which is controlled by pressure sensor 4. Water-alcohol solution not freezing at negative temperatures, is used as hydraulic fluid.

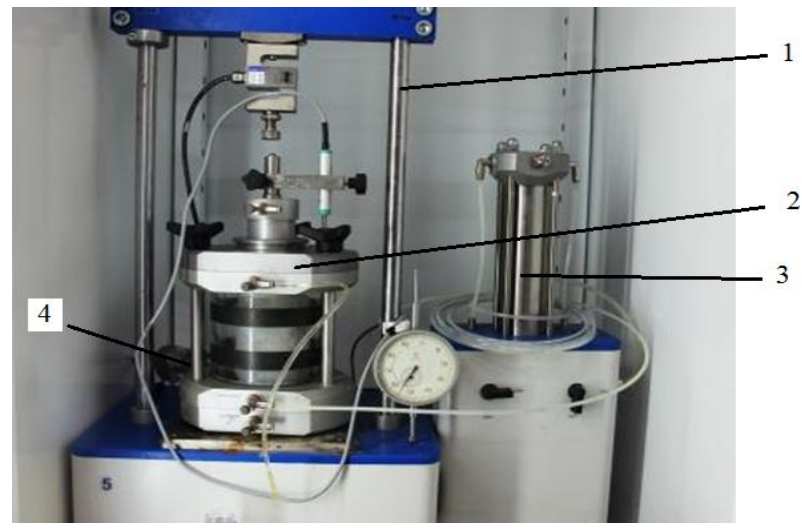

Fig. 1. General view of triaxial compression apparatus ASIS-2

The general view of lateral pressure chamber is on fig. 2 .

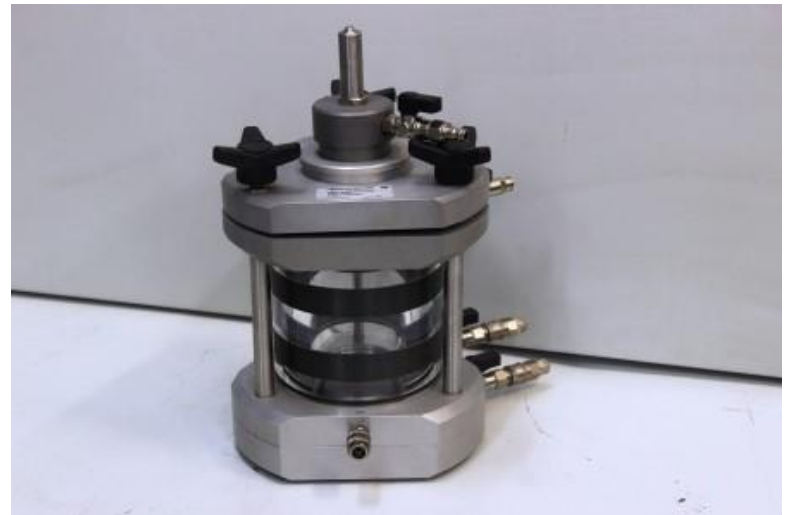

Fig. 2. Triaxial compression chamber 
Laboratory complex ASIS is placed in a freezing room, which should maintain stable negative temperature.

Samples of frozen soil monoliths 10-50 $m$ depth were sorted for the research from Kharasavey gas field located on Yamal peninsula. Mainly, they were represented by loams, clay and sands. The samples were cut by steel cutting ring $80 \times 40 \mathrm{~mm}$, as it is stated by GOST 12248-2010. The experiments were conducted at temperatures $-3{ }^{\circ} \mathrm{C}$ and $-6{ }^{\circ} \mathrm{C}$.

The example of the sample prepared for the experiment is shown on fig. 3 .

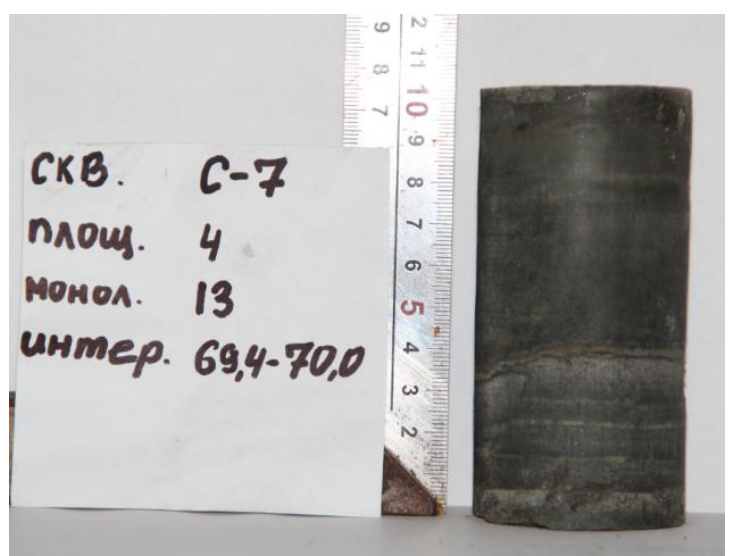

Fig. 3. S-7 core drill prepared for experiment (field 4 , monolith 13, interval $69,4-70 \mathrm{~m}$ )
Constant negative temperature maintenance during the experiment was provided by mobile research laboratory with temperatures range from 0 to $-10^{\circ} \mathrm{C}$.

Before the beginning of test, the sample was placed to pressure shell. The shell was made by special tabular rubber designed by equipment manufacturer. The shell does not cause lateral rebuff during sample strain. Afterwards the sample was placed to the chamber. The chamber was filled by fluid (Wateralcohol solution) with temperature $-15^{\circ} \mathrm{C}$. After the above-listed actions chamber degassing was implemented to the exclusion of discrepancies of sample volumetric strain defining. Axial stress was corrected during the experiment because of the sample cross-section expansion. The results of experiments were processed via STATICA software.

The example of stresses variation during the experiment is shown on fig. 4.

Fig. 5 shows graph of frozen soil creep testing performed at temperature $\mathrm{T}=-3{ }^{\circ} \mathrm{C}$. The initial stress $\sigma_{1}=\sigma_{2}=\sigma_{3}=0,4 \mathrm{MPa}$; step duration $=24$ hours. Transition to increasing creep stage happened when deviator stress $\sigma_{1}-\sigma_{3}$ was equal $2,8 \mathrm{MPa}$.

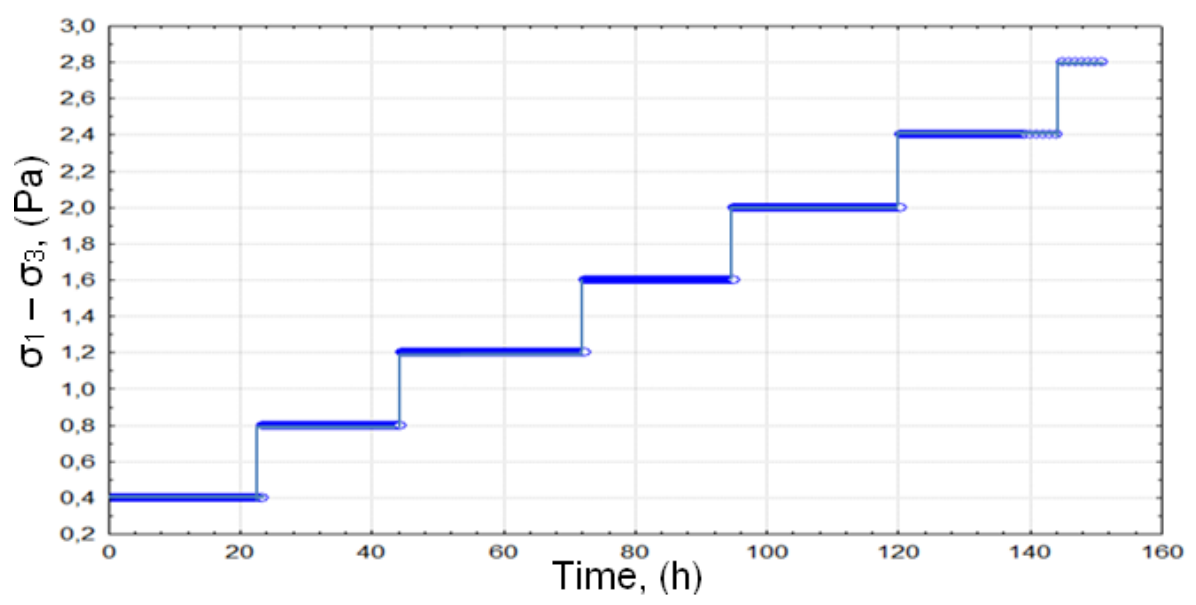

Fig. 4. Loading steps during the experiment 


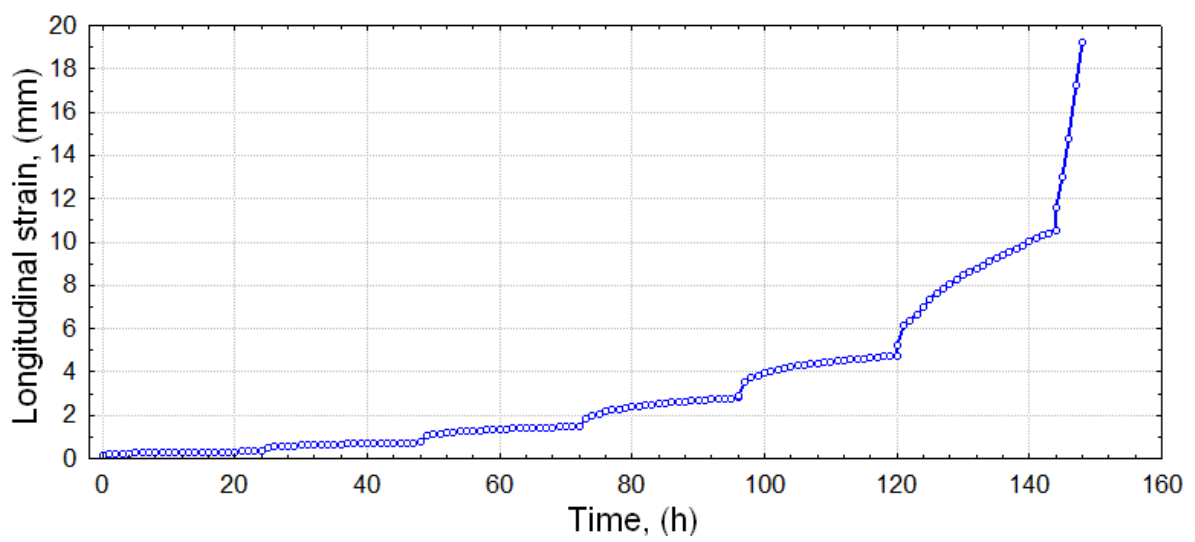

Fig. 5. Graph of frozen soils creep

Experiments described in the article were implemented for the stability calculation of underground constructions using for drill cuttings disposal. The construction of underground reservoirs was implemented via unmanned technology of hydraulic mining. That makes difficulties to estimate their stability, as these underground constructions are unfixed and the surrounding soil massive is affected by heat impact from the disposed product, which changes soil properties significantly.

The specialists of LLC Gazprom Geotechnology make these calculations using certified software ABAQUS where expanded Drucker-Prager model is used. In that case, deformations are described by Eq. 4:

$$
\dot{\epsilon}^{c}=A \times\left(\sigma_{c p}\right)^{n} \times t^{m},
$$

where $\dot{\epsilon}^{c}-$ creep strain rate, $s^{-1}$;

$\sigma_{c p}$ - effective stress, $\mathrm{Pa}$;

$t$ - time, s;

$A ; n ; m$ - coefficients defined through

experiments of soil creep under triaxial compression.

According to Drucker-Prager theory, effective stress $\sigma_{c p}$ is defined in Eq. 5:

$$
\sigma_{c p}=\frac{(P-q \times \operatorname{tg}(\phi))}{(1-0,5 \times \operatorname{tg}(\phi))}
$$

where $P$ - principal stress difference, $\mathrm{Pa}$;

$q$ - the second principal invariant of

the stress deviator tensor, $\mathrm{Pa}$;

$\varphi-$ angle of internal friction, deg.

It is obvious that stresses components should be considered in calculations to realize this model.

\section{Conclusions}

The results of testing were used to calculate input parameters for numerical simulation. The described experiment of frozen soils testing under the conditions of triaxial compression for rheological parameters determination was tested by LLC Gazprom Geotechnology during the designing of underground reservoirs in permafrost required for drill cuttings disposal. Also, similar experiments were implemented by Gersevanov Research Institute of Bases and Underground Structures (NIIOSP).

Furthermore, it can be noted that the experience of the testing implementation described in the article is inconclusive and demands more instructional and experimental research.

\section{References}

1. Ageenko V.A. Development of algorithms for computer-aided design of ground space in the historic center of Moscow on the accession of new territories. Mining informational and analytical bulletin (scientific and technical journal), no. 5, 2012, pp. 358-359. [In Russian]

2. Savich O.I., Karpuhin A.N., Surin S.D. Usage of used chambers of borehole hydroextraction of sand for storage of liquid hydrocarbons and burial of waste of boring on gas and oil and condensate deposits of Yamal Peninsula. Mining informational and analytical bulletin (scientific and technical journal), no. 4, 2010, pp. 298-301. [In Russian]

3. Vakulenko I.S, Smirnov V.I, Surin S.D. Experience of construction and prospects for the use of underground storages for drilling waste in perma- 
frost. Mining informational and analytical bulletin (scientific and technical journal), no. 1, 2016, pp. 222-229. [In Russian]

4. Ageenko V.A., Baklashov I.V. Development of theory and modeling of processes of arching in the vicinity of a tunnel. Mining informational and analytical bulletin (scientific and technical journal), no. 12, 2015, pp. 5-7 [In Russian]

5. Skvortsov A.A, Voronova A.V, Zhuravlyova T.J. Metodika otsenki ustoichivisti podzemnyh reservuarov $\mathrm{v}$ mnogoletnemerzluh porodah [Stabiity determination method of underground storages in permafrost]. The issues of Sergeev's readings conf., 2016, pp. 544-549. [In Russian]

6. Skvortsov A.A,

Voronova A.V, Zhuravlyova T.J.

Modelirovanie geomehanicheskogo povedeniya podzemnyx reservuarov $\mathrm{v}$ mnogoletnemerzlyh porodah [Geomechanical behavior simulation of underground storages in permafrost]. The issues of Engineering Systems conf., 2015, pp. 163-173. [In Russian]

7. Khrulev A.S., Savich O.I., $\quad$ Surin S.D. Aktual'nye tekhnologii obrashcheniya S otkhodami pri stroitel'stve skvazhin. NEFT'GAZTEK [Advanced technologies of waste disposal in well construction: NEFTGAZTEK]. Tumen, 2014, pp. 298-299. [In Russian]

8. Aksyutin O.E., Kazaryan V.A., Ishkov A.G., et. al. Stroitel'stvo i ekspluatatsiya rezervuarov v mnogoletnemerzlykh osadochnykh porodakh [Construction and operation of storages in permafrost sedimentary strata]. Moscow-Izhevsk, NITs "RKhD", Institut komp'yuternykh issledovaniy, 2013, 432 p. [In Russian]

9. Lavrov A. The Kaiser effect in rocks: principles and stress estimation techniques // International Journal of Rock Mechanics and Mining Sciences. 2003, vol. 40, no. 2, pp. 151-171.

10. Razbegin V.N., $\quad$ Vyalov S.S., Maksimyak R.V., $\quad$ Sadovskii A.V. Mechanical properties of frozen soils. Soil Mechanics and Foundation Engineering, no. 33(2), 1996, pp. 35-45.

11. El Hassan Ait Laasri, Es-Said Akhouayri Dris Agliz, Abderrahman Atmani. Automatic detection and picking of $P$-wave arrival in locally stationary noise using cross-correlation. Digital Signal Processing, March 2014, vol. 26. pp. 87-100.

12. Brady B.H.G., Brown E.T. Rock mechanics: for underground mining. Springer Science \& Business Media, 2013.

13. Arenson L.U., Springman, S.M. Triaxial constant stress and constant strain rate tests on icerich permafrost samples. Canadian Geotechnical Journal, no. 42(2), 2005, pp. 412-430.

14. Wang, S., Qi, J., Yao, X. "Stress relaxation characteristics of warm frozen clay under triaxial conditions". Cold Regions Science and Technology, 69(1), 2011, p.112-117.

15. Watson G.H., Slusarchuk W.A., Rowley R.K. Determination of some frozen and thawed properties of permafrost soils. Canadian Geotechnical Journal, no. 10(4), 1973, pp. 592-606.

16. Fish, A.M. Creep and Strength of Frozen Soil Under Triaxial Compression. No. CRREL-SR-9432. COLD REGIONS RESEARCH AND ENGINEERING LAB HANOVER NH, 1994.

17. Chuvilin E.M., Yershov E.D., Naletova N.S., Miklyaeva, E.S. The use of permafrost for the storage of oil and oil products and the burial of toxic industrial wastes in the Arctic. Polar Record, no. 36(198), 2000, pp. 211-214.

18. Andersland O.B., Ladanyi, B. Frozen ground engineering. John Wiley\&Sons, 2004.

19. Johnston G.H. Permafrost: engineering design and construction. J. Wiley, 1981.

20. Zhao X., Zhou G., Chen G., Shang X., Zhao G. Triaxial compression deformation for artificial frozen clay with thermal gradient. Cold Regions Science and Technology, no. 67(3), 2011, pp. 171-177.

\begin{tabular}{|l|l|}
\hline \multicolumn{2}{|c|}{ "Gornye nauki i tehnologii"/ "Mining science and technology", 2017, No. 3, pp. 18-22 } \\
\hline TRItle: & $\begin{array}{l}\text { TRIAXIAL COMPRESSION TESTING OF FROZEN SOILS FOR THE DE- } \\
\text { TERMINATION OF RHEOLOGICAL PARAMETERS }\end{array}$ \\
\hline Author 1: & $\begin{array}{l}\text { Name\&Surname : V.A. Ageenko } \\
\text { Company: National University of Science and Technology "MISIS" } \\
\text { Address: Leninskiy prosp 4, Moscow, Russia, 119049 }\end{array}$ \\
\hline Author 2: & Name\&Surname : M.N. Tavostin \\
\hline
\end{tabular}


Author 3:

\section{DOI:}

Abstract:

Keywords:

References:
Company: National University of Science and Technology "MISIS"

Address: Leninskiy prosp 4, Moscow, Russia, 119049

Work position: Associate professor

Name\&Surname : I.S. Vakulenko

Company: National University of Science and Technology "MISIS"

Address: Leninskiy prosp 4, Moscow, Russia, 119049

10.17073/2500-0632-2017-3-18-22

Detailed investigation of mechanical, deformation and rheological properties of frozen soils is an actual issue, as they are basis of civil-engineering survey for underground constructions in permafrost holding more than $50 \%$ of the territory of Russia. The majority of modern software packages which calculate structures stability considering stress state of soils massive, demand knowledge of mechanical and rheological parameters defined by triaxial compression tests.

The current article presents: estimation method of frozen soils rheological parameters by triaxial compression testing; required equipment and the research results. The samples of frozen soil $10-50 \mathrm{~m}$ depth from Kharasavey gas field were used as test material. Mostly they are presented by loam, clay and sand. The experiments were run at the range of temperature from $-3^{\circ} \mathrm{C}$ to $-6^{\circ} \mathrm{C}$.

Triaxial compression testing was provided by the laboratory equipment which allows to run experiments in the mode of automatic load, maintenance and deformation processes registration. Test procedure of rheological parameters identification under conditions of long-term triaxial compression considered incremental load Stage duration was equal to 24 hours. The experiments were run until th specimen's failure. As a result of the testing, mechanical, deformation and rheological parameters for frozen soils are defined at temperatures $-3^{\circ} \mathrm{C}--6^{\circ} \mathrm{C}$. The achieved results can be interpreted in different models (Mohr-Coulomb, Drucker-Prager, Tresca etc.).

The described experiments were carried out at LLC Gazprom Geotechnology for the design of underground drill cutting s storages in permafrost.

testing of frozen soils, triaxial compression, rheological characteristics, geomechanics

1. Ageenko V.A. Development of algorithms for computer-aided design of ground space in the historic center of Moscow on the accession of new territories. Mining informational and analytical bulletin (scientific and technical journal), no. 5, 2012, pp. 358-359. [In Russian]

2. Savich O.I., Karpuhin A.N., Surin S.D. Usage of used chambers of borehole hydroextraction of sand for storage of liquid hydrocarbons and burial of waste of boring on gas and oil and condensate deposits of Yamal Peninsula. Mining informational and analytical bulletin (scientific and technical journal), no. 4, 2010, pp. 298-301. [In Russian]

3. Vakulenko I.S, Smirnov V.I, Surin S.D. Experience of construction and prospects for the use of underground storages for drilling waste in permafrost. Mining informational and analytical bulletin (scientific and technical journal), no. 1, 2016, pp. 222-229. [In Russian]

4. Ageenko V.A., Baklashov I.V. Development of theory and modeling of processes of arching in the vicinity of a tunnel. Mining informational and analytical bulletin (scientific and technical journal), no. 12, 2015, pp. 5-7 [In Russian]

5. Skvortsov A.A, Voronova A.V, Zhuravlyova T.J. Metodika otsenki ustoichivisti podzemnyh reservuarov v mnogoletnemerzluh porodah [Stabiity determination method of underground storages in permafrost]. The issues of Sergeev's readings conf., 2016, pp. 544-549. [In Russian]

6. Skvortsov A.A, Voronova A.V, Zhuravlyova T.J. Modelirovanie geomehanicheskogo povedeniya podzemnyx reservuarov $\mathrm{v}$ mnogoletnemerzlyh porodah [Geomechanical behavior simulation of underground storages in permafrost]. The issues of Engineering Systems conf., 2015, pp. 163-173. [In Russian] 


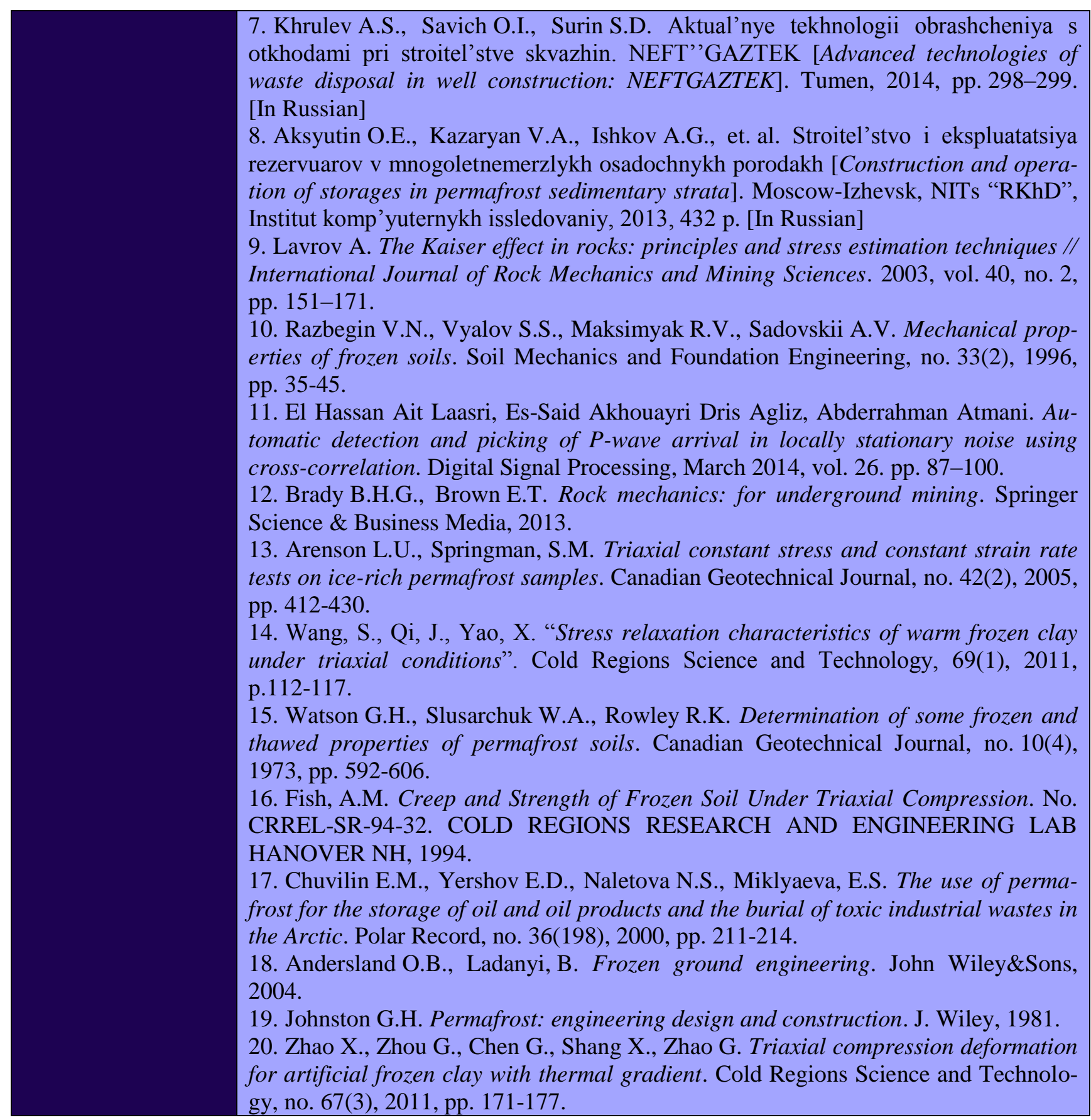

